\title{
Design of high mechanical and thermal resistant composites using marine plant waste
}

\author{
DOI: $10.35530 / I T .069 .06 .1515$
}

SAOUSSEN ZANNEN

RIADH ZOUARI

LAURENCE JEANMICHEL

MOHAMED BEN HASSEN

STEPHANE MOLINA

\section{REZUMAT - ABSTRACT}

Proiectarea compozitelor cu rezistență mecanică și termică ridicată

Au fost investigate proprietățile mecanice și termice ale unei structuri compozite fabricate din matrice de polipropilenă ranforsată cu fibre de deșeuri marine, Posidonia oceanica. Am demonstrat că această fibră disponibilă în mare parte pe coasta mediteraneană prezintă multe avantaje în comparație cu alte fibre naturale utilizate în mod convențional ca armătură. De fapt, fibra Posidonia este extrasă cu ușurință numai prin acțiune mecanică. În plus, aceasta îmbunătățește proprietățile mecanice ale întregului compozit, fără a fi nevoie de compatibilizatori datorită hidrofobiei sale. În cele din urmă, în afară de performanțele mecanice, s-a demonstrat că încorporarea fibrei cu un raport ridicat nu-și degradează proprietățile termice care sunt o specificitate a fibrelor rezistente termic, care ar putea avea ca rezultat producerea unei game variate de aplicații.

Cuvinte-cheie: compozite, fibra Posidonia, performanțe termice și mecanice, tratament pe bază de silan

\section{Design of high mechanical and thermal resistant composites using marine plant waste}

We investigate the mechanical and thermal properties of a composite structure manufactured from polypropylene matrix reinforced with marine waste fibers, Posidonia oceanica. We show that this fiber largely available on Mediterranean coasts presents many advantages compared to other natural fibers conventionally used as reinforcement. In fact, Posidonia fiber is extracted easily with only mechanical action. Moreover, it enhances the mechanical properties of the whole composite without any need of compatibilizers due to its hydrophobicity. Finally, apart from the mechanical performances, we demonstrate that the incorporation of the fiber with high ratio does not degrade its thermal properties which are a specificity of thermally resistant fibers that could open a wide range of applications.

Keywords: composites, Posidonia fiber, thermal and mechanical performances, silane treatment

\section{INTRODUCTION}

The use of natural cellulosic fibers as reinforcements in composite materials has increased thanks to the benefits of these fibers such as ecological aspects, low cost, light weight and high specific modulus [1]. Moreover, compared to high performance fibers such as glass and carbon ones, natural cellulosic fibers present no health risks for manufacture employees or end users. Markets associated to these composites are touching a wide range of applications in many industrial fields like transport and buildings. The thermoplastic polymeric matrices are preferred to thermosets due to their low production cycle and lower costs of processing. Several natural fibers such as hemp, jute and flax have been studied as a reinforcement and filler in thermoplastic polypropylene (PP) matrix to prepare composites [2]. Those studies were performed to investigate and improve the mechanical and thermal performances such as tensile strength, impact strength, young's modulus, thermal stability, etc. Researchers have shown that the compatibility between matrix and fillers is crucial parameter to obtain a low cost with high performances composites as it avoids chemical compatibilization. In this work, we use Mediterranean
Posidonia (Posidonia oceanica) fibers as filler. That is a marine plant which loses leaves in autumn, and its waste deposits can be found mainly along sandy coasts, forming wedge structures, from a few centimeters to several meters thick, denominated "aegagropiles" [3]. These sea wastes are not appreciated by the swimmers because of their bad smell emitted gazes and the pollution caused to beaches. Furthermore, the government incurs significant financial losses to remove that dirt and these wastes are burned or re-immersed in the sea [4]. The valorisation of this available, low price and renewable biomass for the production of environmentally friendly industrial products is an important economic and ecological challenge [5]. Some researches were conducted to explore the use of Posidonia fiber, as a low cost and renewable adsorbent for removing dyes, or as fiber production of cellulosic derivatives [6-7]. Other research works studied the performances of Posidonia fibers as reinforcement for composite materials [8]. They focused on the effects of adding Posidonia fiber on the mechanical and thermal properties of the obtained material using twin screw extruders which damage the fiber structure. In the present work, we propose to study the influence of 
chemical treatment of fibre on thermal and mechanical properties of a composite manufactured from polypropylene (PP) matrix and Posidonia oceanica waste fibers reinforcement. The ecological aspect associated to this fiber does not come only from the valorisation of this natural resource, but also from the ecological extraction method of the fiber itself based on one step mechanical process. Single screw extruder is used to avoid excessive damage of fibers structure.

\section{MATERIALS AND METHODS}

\section{Fibers extraction and composite preparation}

The balls of Posidonia were harvested from the coasts of Tunisia. They were manually frayed and placed on a horizontal opener. The balls opened manually are driven by a rolling lurking and then they are engaged in a threshing cylinder. Subsequently, they are driven by means of a toothed roller in order to separate fibers. By centrifugal force and aspiration, fibers are driven upwardly and the waste falls down. The fiber obtained after this mechanical treatment will be considered as raw fibers. To apply chemical treatment, Posidonia fibers were soaked in aqueous solution containing $1 \%$ by weight of silane coupling agent (aminosilane) and initiator $0.05 \%$, which converts the alkoxysilane groups to silanol. The $\mathrm{pH}$ was adjusted to 3.5 with acetic acid in order to prevent polymerization of silane into polysiloxane. After continuous stirring of the whole mixture for 10 minutes, the fibers were immersed in the solution and the mixture was stirred for one hour. The fibers were subsequently dried in an oven at $60{ }^{\circ} \mathrm{C}$ for 24 hours [9].

To prepare the composite structures, the thermoplastic polymer used as matrix is homopolymer polypropylene (PP). It was in the form of pellets of 3 to 4 $\mathrm{mm}$ in diameter. The treated and non treated fibers were crushed using a crusher RETSCH SK100. After grinding, we carried out a sifting with a sieve of 200 microns and therefore the length of the fibers used for extrusion is between $200 \mu \mathrm{m}$ and $2 \mathrm{~mm}$. The maximum proportion used in fiber was $30 \%$. Beyond this ratio, extrusion was impossible. Then, mixtures of two mass proportions (20\% and $30 \%$ ) were prepared by weighing. The fibers are conditioned at a temperature of $105^{\circ} \mathrm{C}$ before preparing such mixtures. The above mixtures will feed a single screw extruder. The screw is divided to three temperature regions of $190^{\circ} \mathrm{C}$, $200^{\circ} \mathrm{C}$ and $210^{\circ} \mathrm{C}$. To mold our samples, we used thermo-compression. It consists of two parallel plates with controlled temperatures which could be separated in controlled distance allowing inserting a mold. The mold used in this study is a brass one leading to composite plate of $120 \times 120 \mathrm{~mm}^{2}$ with a thickness of
$4 \mathrm{~mm}$. Then, the molding of the composites is carried out as follow: Once the mold has been filled with composite extracted from the extruder, it is placed on the lower plate of the heating press and receives its cover. The upper plate is then slowly lowered until closed and maintained under pressure for $30 \mathrm{sec}-$ onds. Then, the mold is removed from the press and then cooled by means of a cooling system maintained at the temperature of fresh water. Once the mold is cooled, disassembly and extraction of the composite specimen is carried out.

\section{Mechanical analysis of composites}

The tensile test of the specimen were determined using universal testing machine (Instron), according to ISO 527 , with a traveling speed of $0,8 \mathrm{~mm} / \mathrm{min}$ and a cell of $30 \mathrm{kN}$. The distance between clamps for traction is fixed to $60 \mathrm{~mm}$.

\section{Thermal analysis of fiber and composites}

A thermobalance SETARAM SETSYS TG12 was used to study the thermal stability (TGA) of the composite and its components. Samples $(\mathrm{m} \approx 70 \mathrm{mg})$ are placed in a nacelle, and were subjected to a temperature scan from 20 to $700{ }^{\circ} \mathrm{C}$ with a rate of $10{ }^{\circ} \mathrm{C} / \mathrm{min}$ under nitrogen flow (55 $\mathrm{ml} / \mathrm{min}$ ). A combustion step is necessary between two analyzes to remove residual particles in the device. The derivative of TGA curves (DTG) was obtained using TA analysis software.

\section{Fourier transform infrared spectroscopy of Posidonia fibers}

The FTIR spectra of raw and surface treated natural fibers were recorded in a Perkin-Elmer FT-IR spectrometer Frontier which is connected to an ATR accessory. In the ATR technique, the fiber sample is pressed against a crystal (Diamond) and the infrared beam interacts with the sample at the interface. Absorbance was measured over a range from 4000 to $400 \mathrm{~cm}^{-1}$.

\section{RESULTS AND DISCUSSIONS \\ Effect of fiber treatment on mechanical properties of composites}

Table 1 summarizes the mechanical properties associated to the matrix and the composites reinforced with $30 \%$ of raw and treated fibers. These samples are denominated PP, Comp RPF-PP and Comp TPF$P P$, respectively. It demonstrates that addition of fiber increases the Young modulus of the reinforced material and reduces its elongation at break: the plasticity zone of the material is restricted. Therefore, the rigidity of the material increases due to the interaction

Table 1

\begin{tabular}{|c|c|c|c|c|}
\hline Specimen & Fiber weight ratio (\%) & E (Gpa) & $\sigma(\mathbf{M p a})$ & $\varepsilon(\%)$ \\
\hline PP & 0 & $0.88 \pm 0.03$ & $20.34 \pm 0.93$ & $10.53 \pm 0.27$ \\
\hline Comp RPF-PP & 30 & $1.34 \pm 0.07$ & $17.70 \pm 0.66$ & $2.84 \pm 0.34$ \\
\hline Comp TPF-PP & 30 & $1.39 \pm 0.07$ & $19.22 \pm 0.56$ & $2.25 \pm 0.14$ \\
\hline
\end{tabular}


between fibers and matrix. Many researchers have observed the same behavior for natural fibers reinforced thermoplastic matrix and have attributed the improved mechanical properties to increased dispersive interactions [10].

It can be noted also that the reinforcement of polypropylene matrix with Posidonia fibers changes the tensile properties of composite material. Indeed, whatever the nature of the fiber reinforcement (raw or treated) added to the matrix, the Young's modulus increases. Thus, the rate of increase of this mechanical parameter is about $52 \%$ for the raw Posidonia fibers and $58 \%$ for the fibers treated with silane (Comp TPF-PP) compared to pure polypropylene. This affirms well the trend widely illustrated in the literature: the incorporation of compatibilized reinforcements within the matrix contributes to an improvement of the mechanical response of the system $[1,5]$. This enhancement could be attributed to a better dispersion of the fibers within the matrix and that was confirmed with scanning electron microscope images associated to breakage faces of composites shown on figure 1. In fact, we observe more fibers for treated sample attributed to better dispersion within the matrix. Moreover, for both composites, it is clear that slippage between matrix and reinforcements occur during tensile measurements leading to holes or to fibers coming out of the polymer. This result could be explained by the fact that the matrix and fibers adhesion is not based on chemical interaction but on physical affinity. To investigate the treated and untreated fibers surface state, they were submitted to FTIR experiments, which spectra are presented in figure 2 , a. Both bands at $1166 \mathrm{~cm}^{-1}$ and $940 \mathrm{~cm}^{-1}$ represent respectively the $\mathrm{Si}-\mathrm{O}-\mathrm{C}$ and $\mathrm{Si}-\mathrm{OH}$ connections. This proves that the hydroxyl groups of the cellulose were blocked with the silane. Then the fiber's surface becomes more hydrophobic.

This result explains the enhancement of the mechanical properties of composites reinforced with treated fibers. Thus, when the Posidonia fibers were treated with silane, physical affinity occurs leading to better interaction and sticking between matrix and fibers. Nevertheless, even the raw Posidonia fibers contribute to a large increase of the mechanical performances under tensile stress of the composite which constitutes a big advantage of the Posidonia fiber as it does not need any chemical operation neither to be extracted, nor to be dispersed within the hydrophobic matrix. This is due to the hydrophobic character associated to this natural reinforcement experimentally approved [11]. Moreover, comparison between the mechanical properties under tensile stress of polypropylene reinforced with a widely used natural fiber which is raw hemp under the same forming conditions show that Posidonia fibers lead largely to a better Young modulus. In fact, this modulus increases from $1.013 \mathrm{GPa}$ for hemp [10] to 1.34 GPa for Posidonia. This could be attributed to the more hydrophobic character of Posidonia compared to hemp fibers confirmed by the lower content of humidity of $2.1 \%$ for Posidonia fiber versus $10 \%$ for hemp fiber [11-12].

\section{Effect of fiber weight ratio and treatment on thermal properties of composites}

Figure 2,b shows the thermogravimetric behavior DTG of neat polypropylene (Neat PP), raw Posidonia fiber (RPF) and polypropylene matrix reinforced with $30 \%$ of raw Posidonia fiber (Comp RPF-PP (30\%)). We observe that matrix decomposition begins at about $390{ }^{\circ} \mathrm{C}$ and continued until the maximum decomposition temperature at $453.66^{\circ} \mathrm{C}$. At this temperature, the polymer chains are degraded completely. The decomposition is totally completed over $500{ }^{\circ} \mathrm{C}$ and the residual mass is only $3.5 \%$ of the original mass. For Posidonia fibers, there are three mass loss regions: $51-105^{\circ} \mathrm{C}, 225-400{ }^{\circ} \mathrm{C}$ and temperature higher than $400{ }^{\circ} \mathrm{C}$. The first region corresponds to the observed dehydration of the fiber at $105^{\circ} \mathrm{C}$. Beyond this area, and up to $225^{\circ} \mathrm{C}$, the mass varies little which shows good thermal stability. Beyond this temperature, there is a loss of mass resulting in a shoulder on the DTG curve and which is related to the decomposition of the fibers by depolymerizing hemicellulose and pectins at about $277^{\circ} \mathrm{C}$. Maximum degradation occurs at about $322.81^{\circ} \mathrm{C}$ (about $130{ }^{\circ} \mathrm{C}$ lower than the matrix), which reflects the degradation of cellulose. In the case of composite with $30 \%$ of reinforcements, the DTG curves do not correspond to what would be obtained by summing the contributions of each partial component (Posidonia and PP).
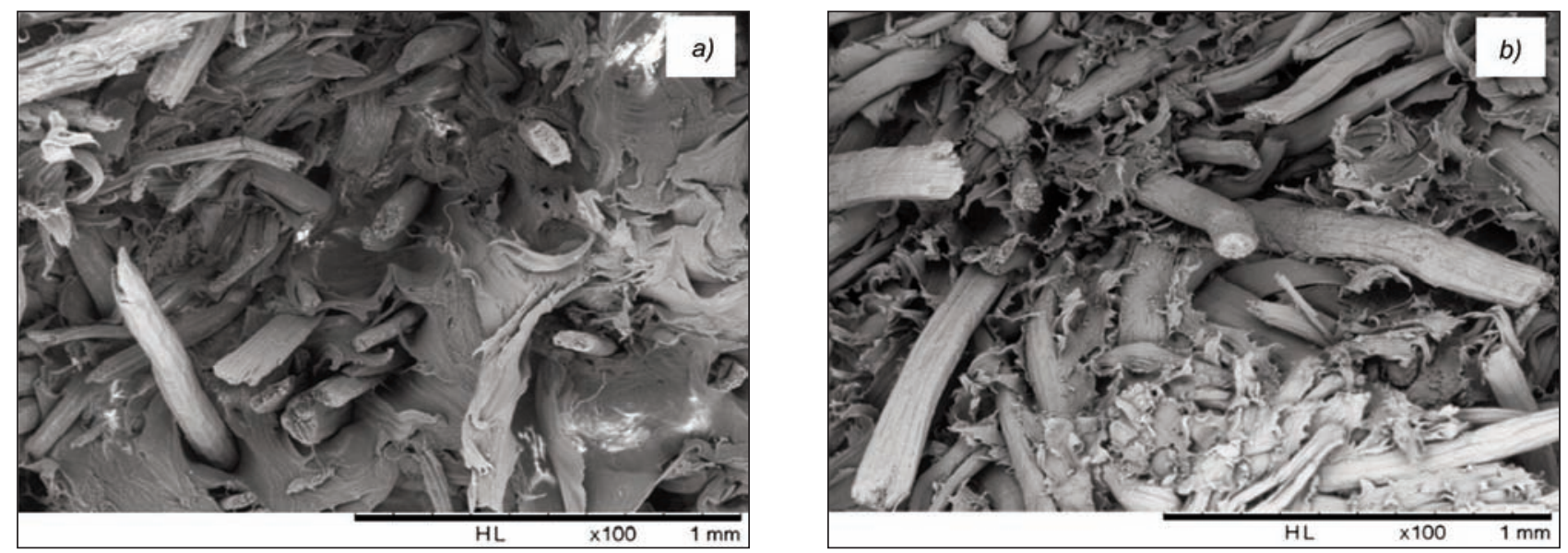

Fig. 1. SEM micrographs of fracture surfaces associated to composites with (a) raw and (b) treated Posidonia fibers 


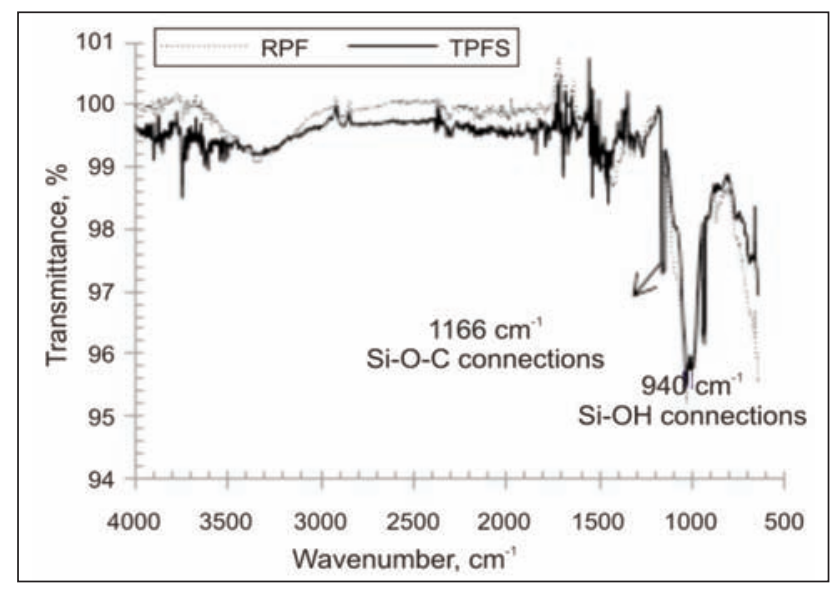

a

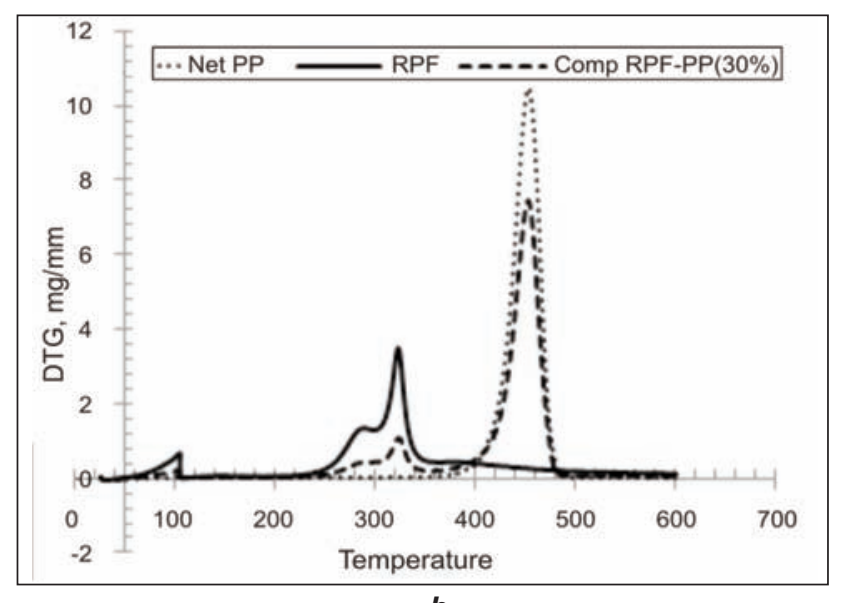

b

Fig. 2. $a$ - FT-IR spectra of untreated (RPF) and treated (TPF) Posidonia fibers; $b$-DTG curves for neat PP matrix, Raw Posidonia Fiber and composite reinforced with $30 \%$ of raw Posidonia fiber (Comp RPF-PP (30\%))

In contrary, we observe a low intensity peak at $\mathrm{T}=323.7^{\circ} \mathrm{C}$, which reflects the degradation of the fiber. This slight shift associated to the decomposition temperature of fibers suggests that the thermal stability of Posidonia oceanica inside the PP matrix is slightly increased. In fact, the matrix that has more resistance to high temperature enrobes the fibers thus having some protecting effect leading to a slight increase of the fiber degradation temperature. Also another peak of high intensity at $452.28{ }^{\circ} \mathrm{C}$ could be observed, which corresponds to the degradation of the polypropylene chains. This peak corresponds to what we observe for neat polymer. From these observations, it is clear that the incorporation of fibers do not affect the overall thermal stability of polypropylene. This characteristic of conserving the thermal stability of composites reinforced with Posidonia fibers is an asset for these natural resources in particular for thermal insulation applications. In fact, most researchers concluded that thermal stability of polypropylene reinforced with other natural fibers decreases once adding fibrous reinforcement.

Jakab et al. noted that the maximum rate of PP decomposition decreases by about $10 \%$ when mixed with wood fibers [13]. Ragoubi et al. reported that adding $20 \%$ of raw miscanthus fibers reduces the maximum temperature of composite degradation by $6{ }^{\circ} \mathrm{C}$ [10]. It was detected at $470{ }^{\circ} \mathrm{C}$ for reinforced composite versus $476{ }^{\circ} \mathrm{C}$ for neat PP matrix. Tajvidi and Takemura found that the overall thermal degradation of the composites obtained by adding of wood flour, kenaf fiber and rice hulls to polypropylene seemed to be an average of the thermal behavior of the component [14]. This asset associated to Posidonia comes from intrinsic properties of this fiber: the surface hydrophobicity and the chemical constitution. In fact, hydrophobicity enhances adhesion between polypropylene matrix and fibers. This physico-chemical affinity is proved to improve the thermal stability of the material [15]. In that latter work, Joseph et al. reported that the thermal stability of the sisal/PP composite was higher than that of the fibre and the neat matrix, due to better fibre-matrix adhesion after alkaline treatment. In addition,
Rahmoune et al. found that soda and silane treatment improve the thermal stability thanks to the fiber structure modification after these chemical and physical treatments [16]. Moreover, the presence of phenolic groups constituting the fiber cells induces a flame retardant character to the fibers, therefore explaining improved thermal stability [17]. This is also confirmed by the important calorific power of Posidonia fiber. In fact, Ntalos G. and Sideras A. reported that Posidonia oceanica has more calorific values than the conventional biomass like bagasse, rice husks and corn cobs [18]. This important calorific value means that this biomass traps more heat which explains their important thermal properties.

\section{CONCLUSIONS}

The use of Posidonia oceanica as reinforcement of thermoplastic polymers is an interesting solution for upgrading this natural waste in beaches and entailing an elevated economical cost for local governments. Polypropylene reinforced with Posidonia oceanica could be used in multiple applications replacing wood and wood like products. Then, in this study we investigated the influence of silane treatment applied to Posidonia fibers on the tensile and thermal properties of reinforced polypropylene composites. Results prove that the young modulus of Posidonia reinforced PP was enhanced and better elastic modulus was obtained when composites were reinforced with fibers treated with silane, compared to raw fibers. Reinforcement with Posidonia oceanica fibers does not induce any degradation to the thermal stability of the matrix which constitutes a great asset relatively to conventional natural cellulosic fibers. This asset comes from intrinsic properties associated to the fiber: surface hydrophobicity and chemical constitution of the fiber containing phenolic groups. In fact, hydrophobicity enhances adhesion between polypropylene matrix and fibers that has a synergistic effect on thermal stability of the material. The presence of phenolic groups induces a flame retardant character to the fibers which improves thermal stability. This work offers environmental friendly materials for a wide range of industrial applications due to its coupling to high mechanical and thermal performances. 
[1] Tudose, V., Coterlici, R. F., Tudosege, D., Gheorghiu, H., Dan Pasrama, S. Study regarding the use of cotton fiber reinforced composite for obtaining protection helmets, In: Industria Textila, 2016, vol. 67, pp 135-140.

[2] Deepak, V. and Siddharth, J. Effect of natural fibers surface treatment and their reinforcement in thermo-plastic polymer composites: A review, In: Current Organic Synthesis, 2017, vol. 14, pp.186-199.

[3] Chessa, L. A., Fustier, V., Fernandez, C., Mura, F., Pais, A., Pergent, G., Serra S. and Vitale, L. Contribution to the knowledge of 'Banquettes' of Posidonia oceanic (L.) Delile in Sardinia Island. In: Proceedings of the 4th International Seagrass Biology Workshop, Biologia Marina Mediterranea, Corsica, France, 2000, vol. 7, pp. 35-38.

[4] Mohamed Ali Wahab, Salah Jellali, Naceur Jedidi, Effect of temperature and pH on the biosorption of ammonium onto Posidonia oceanica fibers: Equilibrium, and kinetic modeling studies, In: Bioresource Technology, 2010, vol. 101, pp. 8606-8615.

[5] Dural, M.U., Cavas, L., Papageorgiou, S.K., Katsaros, F.K. Methylene blue absorption on activated carbon prepared from Posidonia oceanica (L.) dead leaves: kinetics and equilibrium studies, In: Chemical Engineering Journal, 2011, vol. 168 , pp. $77-85$.

[6] Ncibi, M.C., Mahjoub, B., Seffen, M. Investigation of the sorption mechanisms of metal-complexed dye onto Posidonia oceanica (L.) fibres through kinetic modelling analysis, In: Bioresource Technology, 2008, vol. 99, pp. 5582-5589.

[7] Aguir, C. and Mhenni, M.F. Experimental study on carboxymethylation of cellulose extracted from Posidonia oceanic, In: Journal of Applied Polymer Science, 2006, vol. 98, pp. 1808-1816.

[8] Zannen, S., Ghali, L., Halimi, M.T. and Hassen, M.B. Effect of fiber weight ratio and fiber modification on flexural properties of posidonia-polyester composites. In: Open Journal of Composite Materials, 2016, vol. 6, pp. 69-77.

[9] Valadez-Gonzalez, A., Cervantes-Uc, J.M., Olayo, R. and Franco, P.J.H. Effect of fiber surface treatment on the fiber-matrix bond strength of natural fiber reinforced composites, In: Composites Part B: Engineering, 1999, vol. 39, pp. 309-320.

[10] Ragoubi, M., George, B., Molina, S., Bienaimé, D., Merlin, A., Hiver, J.-M., Dahoun, A. Effect of corona discharge treatment on mechanical and thermal properties of composites based on miscanthus fibres and polylactic acid or polypropylene matrix, In: Composites: Part A, 2012, vol. 43, pp. 675-685.

[11] Aguir, C. and M'henni Mohamed Farouk, Chemical modification of Posidonia with cyclic anhydrides: effect on thermal stability, In: Carbohydrate Research, 2010, vol. 345, pp. 264-269.

[12] Alexander, B., Ibon Aranberri-A., and Jürgen, S. Surface characterization of flax, hemp and cellulose fibers; surface properties and the water uptake behavior, In: Polymer Composites, October 2002, vol. 23, no. 5, pp. 872-894.

[13] Jakab, E., Varhegyi, G. and Faix, O. Thermal decomposition of polypropylene in the presence of wood-derived materials, In: Journal of Analytical and Applied Pyrolysis, 2000, vol. 56, pp. 273-285.

[14] Mehdi, T. and Akio, T. Thermal degradation of natural fiber-reinforced polypropylene composites, In: Journal of thermoplastic composite materials, 2010, vol. 23.

[15] Joseph, P.V., Joseph, K., Thomas, S., Pillai, C.K.S., Prasad, V.S., Groeninckx, G., Sarkissova, M. The thermal and crystallisation studies of short sisal fibre reinforced polypropylene composites, In: Composites: Part A, 2003, vol. 34, pp. 253-266.

[16] Rahmoune, M.A., Benhamou, A., Fernane, F., Joumana, T. Effect of treatment with soda and dimethoxydimethylsilane on water absorption and thermal stability of olive pomace flour and date stone, In: Journal of materials and environmental science, 2015, vol. 6, no. 9, pp. 2655-2664.

[17] Castellano, G., Tena, J. and Torrens, F. Classification of phenolic compounds by chemical structural indicators and its relation to antioxidant properties of Posidonia oceanica (L.) delile. In: MATCH Communications in Mathematical and in Computer Chemistry, 2012, vol. 67, pp. 231-250.

[18] Ntalos, G., Sideras, A. The usage of Posidonia oceanica as a raw material for wood composite and thermal energy production, In: Journal of International Scientific Publications: Materials, Methods and Technologies, 2014, vol. 8, pp. 605-611.

\author{
Authors: \\ SAOUSSEN ZANNEN ${ }^{1}$, RIADH ZOUARI ${ }^{1}$, MOHAMED BEN HASSEN ${ }^{2}, 1$, \\ LAURENCE JEANMICHEL ${ }^{3}$, STEPHANE MOLINA ${ }^{4}$ \\ ${ }^{1}$ Textile Engineering Laboratory, Monastir University, Monastir, Tunisia \\ e-mail: saoussenzannen@hotmail.fr, zouaririadh@yahoo.fr \\ ${ }^{2}$ College of Engineering: Industrial Engineering Department, Taibah University Saudi Arabia \\ e-mail: m.benhassen@taibahu.edu.sa; benrayen@yahoo.fr \\ ${ }^{3}$ CETELOR Centre d'Essais Textile Lorraine, Université of Lorraine, Epinal, France \\ e-mail: laurence.jeanmichel@univ-lorraine.fr \\ ${ }^{4}$ LERMAB Laboratoire d'Etudes et de Recherche sur le Matériau Bois, Université of Lorraine, Nancy, France \\ e-mail: stephane.molina@univ-lorraine.fr
}

Corresponding authors:

MOHAMED BEN HASSEN

e-mail:m.benhassen@taibahu.edu.sa; benrayen@yahoo.fr 